\title{
8 \\ National competition policy: Effective stewardship of markets
}

\author{
Alan Fenna
}

\section{Introduction}

In the mid-1990s, Australian Commonwealth and state and territory governments jointly developed, introduced and set about implementing a program of market liberalisation called the National Competition Policy (NCP). The NCP is widely considered a great success - 'a landmark achievement in nationally coordinated economic reform' (PC 2005: viii). As well as being celebrated as a significant and successful suite of economic reforms, it is also hailed as an all-too-rare exercise in successful collaboration between the country's governments. Following the policy assessment framework proposed in the introduction to this volume, this chapter considers the extent to which, and the ways in which, the NCP was an instance of policy success in programmatic, process, political and durability terms. Unlike many other 'policies' evaluated in this volume and elsewhere, the NCP was explicitly named as such-formally articulated and documented, with clear definitions and boundaries-making its characterisation and study more straightforward than might otherwise be the case.

There were certainly ways in which the NCP was a triumph of policymaking, particularly in respect of its implementation. Like even the best policy, of course, the NCP had its difficulties as well as its critics. 
Nonetheless, at the end of the decade of reform, key bodies were able to declare 'mission accomplished'. However, as far as the fundamental test about the degree to which the NCP achieved its stated goal of improving Australian economic performance, it is almost impossible to judge. With regards to the important ways in which the NCP clearly was a success, this chapter canvasses aspects of 'good process' that may have contributed; however, it also draws attention to the unusually favourable conditions that made success much more achievable and likely in this area than in many other policy situations. There are some lessons that can be gleaned from the NCP experience, but all too many of them are of the 'choose your target and your timing wisely' variety.

\section{The policy's architecture}

The NCP was a nationwide, multisectoral program of market liberalisation introduced in 1995 under the auspices of COAG, Australia's peak intergovernmental body. It ran through to 2005, when the last tranche of compensation payments was made to the states and territories and the program concluded. The NCP's main aim was to reduce the cost structure of the Australian economy by introducing competitive market forces to sectors protected by regulation or government ownership or some combination of the two. These, most importantly, were the major network utilities providing Australia's gas and electricity infrastructure as well as water and transport. However, the ambition extended well beyond those to encompass other market restrictions, whether in retailing, privately owned infrastructure or agricultural product marketing. It followed closely the recommendations of the committee of review of the application of the Trade Practices Act 1974 (Cwlth) contained in its report, known as the 'Hilmer Report' (Hilmer et al. 1993).

The NCP was adopted with the signing of three intergovernmental agreements in April 1995. The 'Competition Principles Agreement' committed governments to the structural reform of public monopolies; application of the principle of competitive neutrality, requiring that 'government businesses do not enjoy competitive advantages over private companies as a result of their public ownership' (NCC 2005: 2.1 ); a regime for third-party access to private monopoly infrastructure; and review of legislation to determine whether continued protection of certain markets was warranted. The 'Conduct Code Agreement' 
committed governments to the extension to previously exempt businesses of competition surveillance under the Commonwealth's Trade Practices Act. The 'Agreement to Implement the National Competition Policy and Related Reforms' committed governments to the reform of energy, water and transport industries.

Implementation involved the creation of two new regulatory bodies under the Competition Policy Reform Act 1995. The merger of the Trade Practices Commission and the Prices Surveillance Authority created the Australian Competition and Consumer Commission (ACCC), with a broader mandate to identify and pursue anticompetitive behaviour. And a new body, the National Competition Council (NCC), was established to monitor the NCP's implementation and assess whether progress was sufficient to justify the scheduled reward payments promised to the states and territories by the Commonwealth.

It is important to note that the NCP was one element in a broad suite of reforms pursued by Australian governments at the state and federal levels through that period. Thus, there were a number of cognate liberalising reforms being undertaken or mooted by governments at the time that were not part of the NCP. Neither privatisation nor competitive tendering and contracting out, for example, were part of the NCP. Nor were there any macroeconomic aspects, although there were related developments in this area as well; the NCP was focused exclusively on microeconomic reform.

\section{A policy success?}

As noted above, the NCP has been celebrated-if not feted-as an instance of policy success on a grand scale. The NCC (2005: vii), whose task it was to assess progress of the reform, declared: 'Over the past decade, Australian governments have participated in the most extensive and successful economic reform program in the nation's history.' The OECD's (2005: 11) praise was almost as fulsome, referring to the way that, with the NCP and other reforms, 'Australia became a model for other OECD countries'. More careful evaluation leads, however, to conclusions that are slightly less clear cut and triumphal. Technical assessment is difficult and, while proponents such as the Business Council of Australia were happy with the policy (BCA 2014: 10), there were dissident voices from other sectors. 


\section{Process assessment}

Much well-intentioned and perhaps even well-conceived policy notoriously comes unstuck in the process of implementation. The Ur-text of implementation studies details a quagmire of intergovernmental program failure in the United States in an initiative conceived and directed in Washington, DC, and rolled out in the city of Oakland, California (Pressman and Wildavsky 1973). Such was not the case with the NCP, which was a shining example of intergovernmental collaboration and coordination. In the NCC's (2005: xvii) assessment: 'Many reform objectives under the NCP have substantially been met.' The program was rolled out systematically, with clear objectives, formal assessment and adequate time. There were some derogations and there were some grievances; however, implementation was in general on schedule and comprehensive.

\section{Programmatic assessment}

The thornier question is whether the NCP and its constituent reforms delivered the promised benefits, translating policy outputs into the intended outcomes, without undue costs. Did the NCP achieve its goal of reduction in the cost structure of the Australian economy and a resultant improvement in Australia's competitiveness and economic performance? According to Australia's premier economic policy research and advisory body, the Productivity Commission, the answer is 'yes': the NCP 'has yielded benefits across the community' (PC 2005: viii). Central to this judgement is the commission's view that the NCP 'contributed to the productivity surge that has underpinned 13 years of continuous economic growth, and associated strong growth in household incomes'. Other benefits the commission identified included reducing the price of a number of consumer goods and helping to meet a major environmental goal through 'the more efficient use of water'.

If the NCP did contribute to a 'productivity surge' - and if that surge was the reason for at least the first 15 years of Australia's astonishing run of economic good fortune until the mining boom took over that job-it can certainly be judged a 'success'. However, determining what contribution the NCP made to overall economic performance is far from easy. It is quite possible that other liberalising reforms, such as tariff reduction, were far more important, or that the reforms in general were not the decisive variable. The Productivity Commission's elaboration was: 
While many factors can influence productivity growth, a number of analytical studies indicate that microeconomic reforms-including $\mathrm{NCP}$ - have been a major contributor to Australia's productivity surge in the 1990s, and to the economy's increased resilience in the face of economic disturbances. The reforms have achieved this by increasing the pressures on both private and government businesses to be more productive, through increased competition, while simultaneously enhancing their capacity to respond through more flexible work arrangements, the removal of unnecessary red tape and the like. (PC 2005: 17)

In summary, however, the commission acknowledged that it is not possible to draw an explicit link between specific reforms and the recent improvement in Australia's economic performance' and concluded simply that 'the timing of specific policy changes over the last two decades is strongly suggestive of a link' (PC 2005: 36). This, it barely needs saying, smacks of the fallacy of post hoc ergo propter hoc (Hancock 2005: 28). Such judgements are inevitably contaminated by prior position and ideology and the Productivity Commission's favourable assessment must be read in the context of its tireless advocacy of such reforms. Given this, the most that can be said on the available evidence is that the NCP might have achieved its main goal.

Questions have also been raised about the very idea that competition can be successfully introduced into some of the key industries addressed by the NCP. The 'distorted' markets in the network utilities sector may not be so much the consequence of ideology, interests, public ownership or anachronistic regulation as much as a reflection of the intrinsic challenges of managing natural monopolies and optimising imperfect markets' (Argy 2002). By their nature, the transmission and distribution of electricity, for instance, do not lend themselves to multiple providers and thus genuine competition. Given such economic realities, contrived competition may be the best that can be achieved. 'Structural separation' was intended to inject competitive market forces into the production and sale of electricity but has proven difficult. Similarly, King (2002) has asked what the public interest is in imposing 'competitive neutrality' provisions on government business enterprises and depriving them-and, through them, the consumers they supply - of access to investment capital at government rates. 


\section{Political assessment}

Whether the NCP was a success in political terms is also difficult to judge. In one important regard it obviously was: governments on both sides of politics and at both levels of the federal system supported and persevered with the reforms. Cross-party support continued even through changes of government - a significant test and endorsement (DeightonSmith 2001: 40-1). This continued commitment is particularly notable given the resistance the Labor Party faced from within its ranks and from significant parts of its constituency to further liberalising reforms at the outset (Harman 1996: 215-16).

Did the NCP burnish or did it tarnish the public reputation of policymakers? Did it 'align "good policy" with "good politics"' (Prasser 2006)? This is much less clear. There is little reason to think it was particularly 'good politics', in part because the NCP was seen in some quarters as yet more reform that put markets before people. Peak welfare body the Australian Council of Social Service (ACOSS) argued, for instance, that 'over the period since the introduction of NCP inequality has grown' and that

a key criterion for NCP should be the extent to which it contributes to a reduction in disparities by raising the living standard of people living on low incomes or who are otherwise disadvantaged. (ACOSS 2005: 1)

Whatever contribution the NCP made to the substantial rise in general wealth and the move towards full employment that occurred over the period was too indeterminate to overcome contrary perceptions held by groups viewing the world somewhat differently.

In addition, the NCP became a lightning rod for discontent in parts of rural and regional Australia. From the very beginning, rural interests and their principal parliamentary representatives, the National Party, were deeply ambivalent about the NCP (Harman 1996: 216). This was not surprising given the Hilmer Report (Hilmer et al. 1993: 141) had described Australia's longstanding statutory marketing arrangements for agricultural products as 'often grossly inefficient'. In response to rural agitation, the matter was referred to the Productivity Commission for examination. That inquiry concluded that the NCP would deliver benefits to rural Australia, as it would to Australia as a whole, and the difficulties being experienced in rural and regional areas were largely the product of secular and cyclical market forces or of other (though perhaps related) policies (PC 1999). 
The main direct threat to rural interests was the NCP's push to wind back those statutory marketing arrangements that operated across a range of rural industries from bananas to potatoes, milk and tomatoes to wheat. These were the dominant remaining 'form of assistance to agriculture' (PC 1999: 196). One particularly sticky matter was Australia's 'singledesk' wheat marketing agency, the Australian Wheat Board (AWB). A compromise reform resulted in a situation that was the worst of both worlds: a privatised AWB retaining its single-desk status, which paved the way for the Iraq oil-for-food scandal (Botterill 2012: 91-106). Such difficulties and perceptions may have helped fuel populist discontent as reflected in the rise of Pauline Hanson's One Nation Party.

\section{Endurance assessment}

A policy that is soon eroded or reversed cannot be regarded as successful. In the case of the NCP, however, momentum was maintained over the decade-long implementation period and, in the now more than a decade since mission accomplished was declared, there has been no retreat and no undoing of the policy. The NCP introduced 'general-interest' reforms that 'stuck' (Patashnik 2008). Complaints have since been made that more is not being done, that the reform momentum has been lost and 'complacency' has set in (e.g. Garnaut 2013; King 2015). The Productivity Commission (2005: xxiv-xxxix) immediately urged further reform the moment the NCP officially concluded and business regularly agitated likewise to meet perceived new competitiveness challenges (e.g. BCA 2014). However, there is little sense that existing reforms have been eroded and the slowing pace may well reflect not only the fact that with changing economic conditions (the mining boom, most importantly) the imperative has diminished, but also the fact that many of the most obvious reforms have now been implemented.

\section{How did government get it right?}

Insofar as the NCP was successful, what was the secret to that success? There is no doubt that in this case the government avoided some of the well-known pitfalls of policymaking-pitfalls that have contributed to policy failure in many instances. Contributing to the NCP's success may have been good process and design and an effective implementation framework. 


\section{Good design?}

The NCP experience would seem to be consistent with one of the main lessons Grossman (2013: 179) drew from his review of a litany of 'economic policy disasters': 'reject policy proposals based primarily on ideology.' This seems reasonable; unfortunately, however, distinguishing between policies based primarily on ideology and those that are not is challenging. The idea that the NCP had the benefit of not being ideologically driven is, however, worth considering. To some, it will seem counterintuitive since the reform program of the 1980s and 1990s was criticised at the time for representing the triumph of ideology—variously known as 'economic rationalism' or 'neoliberalism'-over Australia's traditional model of widespread government regulation and public provision (e.g. Valentine 1999). However, in this case, the criticism may have been more ideological in nature than its target.

The primary indication that the NCP was not 'based primarily on ideology' is the fact it was driven by a Labor government at the national level and supported and implemented by Labor as well as Coalition governments at the state and territory level. The NCP was fundamentally bipartisan and reflected a long period of wrestling with the structural challenges of the Australian economy in a way that was informed by both economic theory and empirical observation (Fenna 2015). Labor was pursuing an agenda of economic liberalisation driven not by an ideological attachment to the underlying ideas of market individualism (to which it has never subscribed), but by reluctant conviction that these reforms were essential to the health and functioning of the Australian economy. The Liberal Party, meanwhile, demonstrated a much deeper affection for market liberalism that had been made painfully clear by its 'Fightback!' manifesto (Liberal Party of Australia 1991), which helped the Coalition lose 'the unlosable' 1993 federal election. The Liberals took a more ideological stand on the NCP, 'itemising the manner in which the Keating government was not pursuing a consistent line on competition on labour, the airlines, shipping and telecommunications infrastructure' (Harman 1996: 216). Winning the federal election only a year after the NCP was set in motion, the Coalition parties set about expanding the market liberalisation agenda with much more ideologically driven policy_most controversially in the industrial relations domain, culminating in the highly controversial 2005 'WorkChoices' legislation. 


\section{Good process?}

It is common to point to good process as important in generating good policy (e.g. McConnell 2010; IPAA 2012). The chief lesson King and Crewe (2013) drew from the litany of governmental blunders they detailed in the United Kingdom is the importance of deliberative processes. Much bad policy would have been improved or rejected, they argue, in a more deliberative environment where ideas had to be tested at the conception stage before being found wanting in application. Australia's experience with the NCP would seem to be consistent with this emphasis on 'good process'. A researched basis for the policy was put forward by the Industry Commission (IC 1990). Rationale and framework were developed at length in the Hilmer Report (Hilmer et al. 1993). Most importantly, the NCP had to be negotiated through COAG and receive the endorsement and cooperation of the states and territories. Federalism was deeply implicated in the NCP and the policy was a key moment in Australian federalism (Painter 1998; Phillimore and Fenna 2017). One consequence of this was acceptance by the Commonwealth of the need to provide compensation payments to the states and territories (discussed below). The gestation period was five years.

Another consequence was that the implementation arrangements played to one of the strengths of federalism by leaving responsibility for the manner of reform to individual jurisdictions (Harman and Harman 1996). Accommodation could thereby be made for both the differing circumstances and preferences of the different jurisdictions and the fact that the different sides of politics were bound to have different notions of how far liberalisation and privatisation should go. This was particularly the case in respect of some of the largest questions, such as how to reform the state electricity systems. This is not to say the NCP entirely lived up to its promise and always accommodated legitimate or benign states' diversity of preferences (Churchman 1996; Charles 2001; Harwood and Phillimore 2015: 257).

\section{Effective implementation?}

What did government do that helped make the NCP an implementation success story? In the main, the answer would seem to be the way the task was delegated to the state and territory governments but overseen by a joint oversight body, the NCC, which was charged with assessing whether sufficient progress had been made for distribution of the 
promised financial sweeteners. The Commonwealth was not itself trying to reach across the country and manage policy with the associated risks that carries. At the same time, the assessment body was truly 'federal' in its constitution, rather than an arm of the Commonwealth, and thus was considered 'a fair and reasonable broker' by the states and territories (Harwood and Phillimore 2015: 253). And finally, the Commonwealth distributed approximately $\$ 5.7$ billion in reward payments to the states and territories over the life of the policy (PC 2005: 29). These were widely 'regarded as being crucial to the successful implementation of the NCP' (Harwood and Phillimore 2015: 254; see also Deighton-Smith 2001: 37). Contributing to their efficacy was the fact that, rather than upfront funding, the reward payments were provided only after the fact, once the agreed reforms had been implemented.

\section{Getting it right or having it easy?}

Against the idea that the NCP was successful because government did the sorts of things that would make it successful must be weighed the not insignificant factors that were particularly conducive to policy success in this case. These factors substantially dilute the sense that government got it right by doing it right and thereby, unfortunately, diminish the utility of any lessons that might be learned.

\section{A ‘tame' problem}

'The difficulty with policy often begins with the selection of unrealizable aims' (Ingram and Mann 1980: 19). This is indeed the case with many policy objectives and, as Ingram and Mann pointed out almost 40 years ago, the expectations of government propel policy in the direction of failure. If anything, the complexity and difficulty of these demands have increased since then and bedevil policymaking even more (Schuck 2014). Although Rittel and Webber (1973) argue that the problems addressed by public policy are in general 'inherently wicked', consensus holds that some of those problems are rather more wicked than others-indeed, perhaps considerably more wicked than others.

The NCP, it must be emphasised, was not addressing a particularly wicked problem. It was not dealing with a profound values dispute (few disagreed with the idea that making markets work better to deliver higher levels of economic growth was a good thing). It was not dealing with intractable social problems. It was not caught up in deep and often zero-sum conflicts 
such as that between industrialism and the environment. It did not involve the risky and controversial business of 'picking winners'. It did not involve the kind of ambitious investment and construction program that has often proven so challenging for governments. It did not involve the rolling out of administratively complex programs. And, it did not embroil the government in conflicts with powerful private-sector opponents-as, for instance, occurred in the more recent mining tax debacle (Marsh et al. 2014). On the contrary, it was strongly supported by business, particularly big business (Harman 1996). The current Chairman of the Productivity Commission has protested that the NCP 'was not the plucking of lowhanging fruit' (Harris 2014: 9). Perhaps it was not; however, it was the plucking of fruit that was within reasonable grasp. If you want successful policy, the obvious lesson is to tackle the eminently feasible. The NCP was well down the wickedness scale.

\section{Prestructured deliberation}

As acknowledged above, the NCP did benefit from a healthy amount of deliberation; however, this occurred largely as a consequence of Australia's federal system. Because the main targets of the NCP were state and territory government instrumentalities, the Commonwealth had to rely more on suasion and inducement than coercion. As a consequence, compromises were forced on the Commonwealth-compromises that certainly made the policy more viable. In particular, the Commonwealth was obliged to concede more collaborative institutions (the NCC), greater flexibility in implementation and reward payments. Insofar as the NCP was a triumph of cooperative federalism, that cooperative approach occurred as much out of necessity as out of prudent policymaking — and, even then, it did represent, in a soft power form, yet another expansion of the Commonwealth's influence over the states (Hollander 2006).

\section{Preexisting momentum}

Political and economic circumstances were particularly auspicious for the NCP. Politically, the path to the NCP had been well and truly smoothed by a decade of successful economic reform. The NCP was in many ways merely the logical and more systematic extension of what Australia's federal and state and territory governments had been doing for a decade. Pioneering reform of state electricity systems and movement towards the National Electricity Market were, for instance, well under way by the time the NCP was introduced (KPMG 2013; see also Wood and 
Blowers 2018). Competition policy was part and parcel of the historic policy shift initiated by the Hawke Labor Government at the national level in 1983. Beginning with what was then seen as the radical decision to end fixed exchange rates for the Australian dollar, the program gathered speed through the 1980s, focusing on reduction of protective tariffs, privatisation of major government business enterprises and the cautious winding back of national wage-setting. This sea change came in response to a deep malaise in the Australian economy as the country's original growth model reached its limits (Fenna 2013).

Much less had occurred at the state level, which was not insignificant given the enormous role the states and territories play in regulation and infrastructure provision. 'Ironically, reform in the states was impeded by Commonwealth policies' (Painter 1998: 35). The large state-owned utilities paid substantial dividends into state treasuries; those would diminish if more competitive environments were introduced and would transmute altogether into Commonwealth Government tax revenue if the enterprises were privatised. In this context, the NCP was merely facilitating developments that were already under way or being held back.

Economically, the NCP benefited from two adventitious but very convenient economic factors. One was that, as a result of excess capacity in the electricity sector, prices came down over the period and thus reform seemed to be paying immediate dividends (Argy 2002: 38). The other was that the economy performed awfully well. After the 1990-92 recession, Australia enjoyed what Ross Garnaut (2013: 5) called, perhaps rather extravagantly, 'the longest unbroken period of economic expansion of any developed country ever'. This extraordinary run of good fortune over the entire period of the NCP and beyond contributed to the policy's 'success' in both subjective and objective terms. In subjective terms, it was bound to make a policy that was aimed at improving economic performance look like it was doing its job, even if-as discussed above-causality is extremely difficult to attribute. In objective terms, the policy also operated in a highly conducive environment as a consequence of a thriving economy. A significant risk in such policies is the potentially derailing effect of 'transitional costs': the problem that short-term adjustment pain will if not exceed, then possibly overshadow, short and medium-term general gain. Mitigation or minimisation of those costs becomes, then, an important contributor to success. In this case, liberalisation critic John Quiggin (1997: 256) insisted soon after the NCP was launched: 
[T] he dominant flow-on effects of microeconomic reform will be negative, arising from the fact that at least some of the workers directly displaced by reform will be permanently displaced from the employed labour force.

But this was scarcely the case; before long, continuing economic growth drove the labour market to as close to full employment as had existed since the postwar boom. Economic conditions thus worked to minimise one of the major risks associated with reformist policymaking of this nature.

\section{Conclusion}

No policy is without its blemishes and Australia's NCP is no exception. Rural reforms proved problematic in some sectors and a rural backlash occurred. Electricity reform remains challenging, with, among other things, state governments in Queensland and New South Wales expending considerable political capital pursuing privatisation. However, it certainly was not a policy failure, let alone that most scandalous but apparently not so rare event, a policy fiasco. The NCP was a well-considered policy linked to an effective implementation strategy that by and large achieved the policy's output aims without causing excessive collateral damage. Whether it achieved its intended outcomes is difficult if not impossible to judge authoritatively, but the evidence suggests it did contribute to Australia's ongoing economic success. Any realistic assessment of the NCP must acknowledge, however, that the success it enjoyed was due in no small part to the straightforward nature of its objectives compared with many of the nasty policy challenges governments face, the requirements for consultation and collaboration imposed by Australia's federal system, the broader reform momentum of which it was part and the extraordinarily good economic times in which it played out. Here virtù and fortuna seem to have nicely aligned, with auspicious conditions and good policymaking conspiring to produce policy success.

\section{References}

Argy, F. 2002. 'National competition policy: Some issues.' Agenda 9: 33-46.

Australian Council of Social Service (ACOSS) 2005. National Competition Policy: ACOSS submission to the Productivity Commission. Sydney: ACOSS. 
Botterill, L. C. 2012. Wheat Marketing in Transition: The transformation of the Australian Wheat Board. New York: Springer. doi.org/10.1007/978-94-0072804-2.

Business Council of Australia (BCA) 2014. Submission to the Competition Policy Review. Melbourne: BCA.

Charles, C. 2001. 'Reflections on national competition policy.' Australian Journal of Public Administration 60: 120-1. doi.org/10.1111/1467-8500.00233.

Churchman, S. 1996. 'National competition policy: Its evolution and implementation-A study in intergovernmental relations.' Australian Journal of Public Administration 55: 97-9. doi.org/10.1111/j.1467-8500.1996.tb 01208.x.

Deighton-Smith, R. 2001. 'National competition policy: Key lessons for policymaking from its implementation.' Australian Journal of Public Administration 60: 29-41. doi.org/10.1111/1467-8500.00222.

Fenna, A. 2013. 'The economic policy agenda in Australia, 1962-2012.' Australian Journal of Public Administration 72: 89-102. doi.org/10.1111/1467-8500. 12020 .

Fenna, A. 2015. 'The economic context of policy analysis in Australia.' In B. Head and K. Crowley (eds), Policy Analysis in Australia. Bristol: Policy Press.

Garnaut, R. 2013. Dog Days: Australia after the boom. Melbourne: Redback.

Grossman, R. S. 2013. Wrong: Nine economic policy disasters and what we can learn from them. New York: Oxford University Press.

Hancock, K. 2005. 'Productivity growth in Australia 1964-1965 to 2003-04.' Australian Bulletin of Labour 31: 28-32.

Harman, E. 1996. 'The National Competition Policy: A study of the policy process and network.' Australian Journal of Political Science 31: 205-24. doi.org/ 10.1080/10361149651193.

Harman, E. J. and Harman, F. L. 1996. 'The potential for local diversity in implementation of the National Competition Policy.' Australian Journal of Public Administration 55: 12-25. doi.org/10.1111/j.1467-8500.1996. tb01196.x.

Harris, P. 2014. Competition Policy and Deregulation: Challenges and choices. Canberra: Crawford School of Public Policy, The Australian National University. 
Harwood, J. and Phillimore, J. 2015. 'National competition policy and cooperative federalism.' In J. Wanna, E. A. Lindquist and P. Marshall (eds), New Accountabilities, New Challenges. Canberra: ANU Press.

Hilmer, F. G., Rayner, M. and Taperell, G. 1993. National Competition Policy: Report by the Independent Committee of Inquiry. Canberra: Commonwealth of Australia.

Hollander, R. 2006. 'National competition policy, regulatory reform and Australian federalism.' Australian Journal of Public Administration 65: 33-47. doi.org/10.1111/j.1467-8500.2006.00480.x.

Industry Commission (IC) 1990. Annual Report 1989-90. Melbourne: Industry Commission.

Ingram, H. M. and Mann, D. E. 1980. 'Policy failure: An issue deserving analysis.' In H. M. Ingram and D. E. Mann (eds), Why Policies Succeed or Fail. Beverly Hills, CA: Sage Publications.

Institute of Public Administration Australia (IPAA) 2012. Public Policy Drift: Why governments must replace 'policy on the run' and 'policy by fiat' with a 'business case' approach to regain public confidence. Canberra: IPAA.

King, A. and Crewe, I. 2013. The Blunders of Our Governments. London: Oneworld Publications.

King, S. 2015. 'Competition policy and the competition policy review.' Australian Economic Review 48: 402-9. doi.org/10.1111/1467-8462.12134.

King, S. P. 2002. 'The economics of national competition policy.' Law in Context 20: 6-33.

KPMG 2013. National Electricity Market: A case study in successful microeconomic reform. Sydney: Australian Energy Market Commission.

Liberal Party of Australia 1991. Fightback! Taxation and expenditure reform for jobs and growth. Canberra: Liberal Party of Australia.

McConnell, A. 2010. Understanding Policy Success: Rethinking public policy. Basingstoke, UK: Palgrave Macmillan.

Marsh, D., Lewis, C. and Chesters, J. 2014. 'The Australian mining tax and the political power of business.' Australian Journal of Political Science 49: 711-25. doi.org/10.1080/10361146.2014.954985.

National Competition Council (NCC) 2005. Assessment of Governments' Progress in Implementing the National Competition Policy and Related Reforms: 2005. Melbourne: NCC. 


\section{SUCCESSFUL PUBLIC POLICY}

Organisation for Economic Co-operation and Development (OECD) 2005. OECD Economic Surveys: Australia. Paris: OECD Publishing.

Painter, M. 1998. Collaborative Federalism: Economic reform in Australia in the 1990s. Melbourne: Cambridge University Press. doi.org/10.1017/CBO9780 511552236.

Patashnik, E. M. 2008. Reforms at Risk: What happens after major policy changes are enacted. Princeton, NJ: Princeton University Press.

Phillimore, J. and Fenna, A. 2017. 'Intergovernmental councils and centralization in Australian federalism.' Regional and Federal Studies 27: 597-621. doi.org/ 10.1080/13597566.2017.1389723.

Prasser, S. 2006. 'Aligning "good policy" with "good politics".' In H. K. Colebatch (ed.), Beyond the Policy Cycle: The policy process in Australia. Sydney: Allen \& Unwin.

Pressman, J. L. and Wildavsky, A. 1973. Implementation: How great expectations in Washington are dashed in Oakland; Or, why it's amazing that federal programs work at all; this being a saga of the Economic Development Administration as told by two sympathetic observers who seek to build morals on a foundation of ruined hopes. Berkeley, CA: University of California Press.

Productivity Commission (PC) 1999. Impact of Competition Policy Reforms on Rural and Regional Australia. Melbourne: Productivity Commission.

Productivity Commission (PC) 2005. Review of national competition policy arrangements. Inquiry Report, 14 April. Melbourne: Productivity Commission.

Quiggin, J. 1997. 'Estimating the benefits of Hilmer and related reforms.' Australian Economic Review 30: 256-72. doi.org/10.1111/1467-8462.00025.

Rittel, H. W. J. and Webber, M. M. 1973. 'Dilemmas in a general theory of planning.' Policy Sciences 4: 155-69. doi.org/10.1007/BF01405730.

Schuck, P. H. 2014. Why Government Fails So Often: And how it can do better. Princeton, NJ: Princeton University Press.

Valentine, B. 1999. 'National competition policy: Legitimating economic rationalism.' Australian Social Work 52: 26-31. doi.org/10.1080/031240 79908414106.

Wood, A. and Blowers, D. 2018. Mostly Working: Australia's wholesale electricity market. Melbourne: Grattan Institute. 
This text is taken from Successful Public Policy: Lessons from Australia and New Zealand, edited by Joannah Luetjens, Michael Mintrom and Paul 't Hart, published 2019 by ANU Press, The Australian National University, Canberra, Australia.

doi.org/10.22459/SPP.2019.08 